\title{
Literature Study On The Effect Of On The Job Training On Work Readiness
}

\author{
Bambang Junipitoyo $^{1^{*}}$, I Wayan Susila ${ }^{2^{*}}$, Any Sutiadiningsih ${ }^{3}$ \\ 1,2,3 Vocational Education Department, Universitas Negeri Surabaya, Indonesia \\ ${ }^{1}$ Aircraft Engineering Department, Politeknik Penerbangan Surabaya, Indonesia \\ ${ }^{*}$ Corresponding author: \\ Email: bambang.junipitoyo@yahoo.com
}

\begin{abstract}
.
Experience on the job training will help students improve the competence of graduates to align with what is needed. In addition to developing competencies, learning through experience on the job training will stimulate the development of character and also a work ethic of discipline, responsibility, honesty, cooperation, leadership, and others according to what is needed by the industry. The creation of competence, character and work ethic is expected that graduates will be ready to welcome the competition of the ASEAN Economic Community (AEC). This research was conducted based on a literature study of various theoretical studies regarding experiences on the job training. Where these studies are an initial description in conducting research, especially those related to the influence of experiences on the job training. Based on the results of data analysis with several similar research literature, the effect of on the job training experience on graduate work readiness is very significant and it can be concluded that there is a significant effect on the job training experience on graduate work readiness.
\end{abstract}

Keywords: Experience on the job training, Work Readiness, Competence

\section{INTRODUCTION}

The quality of human resources is the potential for the success of national development. The quality of human resources can be developed through an educational process. the better the quality of education, the greater the opportunity for human resources to develop. The quality of education must be able to keep up with developments and changing times

The Central Statistics Agency (BPS) in August 2018, of the 131.01 million people who entered the labor force, there were 124.01 million people working, and the remaining 7 million people were confirmed to be unemployed.

But in fact what happened was not in accordance with the goals and expectations of the Polytechnic. In some industries, for example, there are still many graduates who are not ready if they have to go directly into industries related to engineering.

Nugroho (2011: 46) states that the competencies expected by the industry are skills in accordance with their fields (hard skills) and competence attitudes, cooperation, motivation which are classified as soft skills. On average, schools in http://ijstm.inarah.co.id 
Indonesia have not formed graduates to have the two skills above and in the end graduates will find it difficult to compete in the world of work. So it takes training or training that takes a long time so that graduates from this polytechnic are truly ready to jump in and work in industry. Thus education in polytechnics can be interpreted as not running effectively nor efficiently when compared to the goals of vocational education at the polytechnic itself.

The government develops vocational education in polytechnics with an on the job training program with the aim of aligning what is taught at the polytechnic with what is needed in the world of work. It can be concluded that on the job training is the development of students' abilities to add experience to the world of work directly which can be used in equipment maintenance, human resource enhancement, etc. as well as to provide students with real real work experience. So that the experience on the job training is applied based on two interests, namely academic and non-academic interests. Academic deals with learning aimed at students and non-academics related to what is produced by educational institutions in creating good quality graduates in the form of soft skills and skills.

Experience on the job training will help students improve their competence in order to align with what is needed by the industrial world. In addition to developing competencies, learning through experience on the job training will stimulate the development of character and also a work ethic of discipline, responsibility, honesty, cooperation, leadership, and others according to what is needed by the industry. It is hoped that the polytechnic graduates will be ready to welcome the competition of the ASEAN Economic Community (AEC) to create competence, character and work ethic.

The on the job training program is a breakthrough for the world of education in Indonesia. With the aim of creating competent and ready-to-work polytechnic graduates in accordance with the demands of the world of work, work-based learning is one of the solutions. The implementation of on the job training also in polytechnics is a form of one effort.

\section{METHODS}

This research was conducted based on a literature study of various theoretical studies regarding on the job training. Where these studies are an initial description in conducting research, especially those related to the effect of on the job training. Here are some research related to on the job training:

a. The Impact of Employees Training On the Job Performance in Education Sector of Pakistan (Amin, 2012): This study was conducted to find out that training and development exist in the education sector and its impact is to produce employee efficiency to meet the needs of their customers.

b. The Effects of On-the-job and Out-of-Employment Training Programs on Labor Market History (Blasco, 2012): This study aims to evaluate the impact of onthe-job training and outside of the workplace on mobility in the labor market. Participation in training has a lasting effect on the trajectory of the individual 
c. A Study of on the Job Training Effectiveness: Empirical Evidence of Iran (Alipour, 2009): Training is very important for the growth and economic welfare of a nation. This need for training covers all levels of industry, to the national level where the welfare of a country is increased by training, to any enterprise where productivity is increased, to individuals whose skills are upgraded and as a result, improve their position in the workplace.

d. Situated Learning and Planned Training on the Job (Stein, 2001): This study proposes that the available learning constructs provide a framework for understanding the training planned in the workplace. By studying and working in the same location, there is a greater likelihood that job performance can provide content for learning.

e. Using Expert Employees to Train on the Job (Johnson, 2001): An essential component of an effective OJT is the development of experts as effective trainers. This article examines the nature of employee expertise in terms of its importance to instructional effectiveness and discusses the value of using employees to convey what they know and can do in person.

f. Deductive and Inductive on-the-Job Training Strategies (Lohman, 2001): Historically planned workplace training programs use deductive training strategies as a means of delivering training content. In addition, alternative training strategies, such as inductive approaches, should be considered in response to job demands. This study compares deductive and inductive training strategies and presents the factors to consider when selecting strategies for planned job training

g. Cross-Cultural Implications of Planned on-the-Job Training (Osman-Gani, 2001): This study discusses these issues related to culture of planned job training.

h. Structured on-the-Job Training in Developing Nations (Stolovitch, 2001): This study presents the rationale for structured OJT in this setting, describing a model adapted to fit a developing country context.

\section{RESULT AND DISCUSSION}

This research was conducted based on a literature study of various theoretical studies regarding on the job training. Where these studies are an initial description in conducting research, especially those related to the effect of on the job training. Here are some research related to on the job training:

a. This beta value shows the magnitude of changes in the dependent variable (Job Performance) due to changes in independent variables (Training Benefits, Development, on time Training, Organizational Policies, On the Job and Off the Job Training)

b. We find that there is an interdependence between the two types of training. Participation in training has a lasting effect on the trajectory of the individual.

c. The results of this study indicate that on the job training is very influential on creativity, achievement of organizational goals and improving work quality. 
d. The important thing in learning lies in the construction of work content; work context; and the availability of a working community to guide and assist in planning, interpreting experiences, and constructing learning.

e. Training principles and strategies to better prepare content experts to become effective workplace trainers are presented

f. Alternative training strategies, such as the inductive approach, should be considered in response to job demands. Although inductive training strategies hold much promise for developing higher order cognitive skills, they are not without limitations

g. There is a growing awareness that cultural mismatch can hinder the effectiveness of training and that this undesirable effect can become more pronounced when training is carried out in the workplace and when trainers and trainees come from different cultural backgrounds.

h. Structured on-the-job training (structured OJT), adapted to a developing country environment, can significantly improve, at low cost, workers' performance capabilities.

\section{CONCLUSION}

Effective training improves people's knowledge, skills, attitudes and behavior and hence their performance. Increasing individual performance leads directly to benefits. On the job training has a positive effect on creativity, goal achievement, and economic benefits. With the excellence that is the dedication of training for the organization, organizations with high ambitions must carry out the training to achieve these benefits.

\section{ACKNOWLEDGMENTS}

The authors would like to thank the entire Universitas Negeri Surabaya for supporting this literature study, to the head of the S3 Vocational Education Study Program and to the Politeknik Penerbangan Surabaya. We also thank all lecturers at the Universitas Negeri Surabaya for their invaluable advice and guidance.

\section{REFERENCES}

[1] A'la, A. (2006). Pembaharuan Pesantren. Yogyakarta: Pustaka Pesantren.

[2] Alipour, M., Salehi, M., \& Shahnavaz, A. (2009). A study of on the job training effectiveness: Empirical evidence of Iran. International journal of business and management, 4(11), 63-68.

[3] Anam Amin, R. S., \& Lodhi, M. R. N. (2013). The impact of employees training on the job performance in education sector of Pakistan. Middle-East Journal of scientific research, 17(9), 1273-1278. 
International Journal Of Science, Technology \& Management

[4] Arumsari, Dian. 2017. Pengaruh Media Pembelajaran dan Keterampilan Pengelolaan Kelas Terhadap Prestasi Belajar Siswa SMK Negeri 5 Madiun, Jurnal Akuntansi dan Pendidikan, VOL. 6 (1) hal 13-25

[5] Asfaw, A. M., Argaw, M. D., \& Bayissa, L. (2015). The Impact of Training and Development on Employee Performance and Effectiveness: A Case Study of District Five Administration Office, Bole Sub-City, Addis Ababa, Ethiopia. Journal of Human Resource and Sustainability Studies, 188-202.

[6] Atmoko, I. D., Sawiji, H., \& Susilowati, T. (2012). Implementasi Program On The Job Training (OJT) Dalam Mempersiapkan Siswa SMK Memasuki Dunia Kerja. Jurnal Pendidikan Administrasi Perkantoran Universitas Sebelas Maret, 1(1), 116874.

[7] Barron, J. M., Black, D. A., \& Loewenstein, M. A. (1989). Job matching and on-the-job training. Journal of labor Economics, 7(1), 1-19.

[8] Blasco, S., Crépon, B., \& Kamionka, T. (2012). The effects of on-the-job and out-ofemployment training programmes on labour market histories. Documents de travail du Centre pour la Recherche Économique et ses Applications (Cepremap).

[9] Dessler, Gary. 2006. Manajemen Sumber Daya Manusia. Jilid 1 Edisi Kesepuluh. Jakarta: PT INDEKS

[10] Dewi, S. R. (2018). Analisis Dominasi Pengaruh On The Job Training Terhadap Peningkatan Kualitas Kinerja. Jurnal Manajemen, 8(1).

[11] Han, B., \& Kong, J. (2018, July). Research on Cultivating and Enhancing the SelfDevelopment Ability of the Poor Ethnic Minority Population. In 2018 4th International Conference on Economics, Social Science, Arts, Education and Management Engineering (ESSAEME 2018). Atlantis Press.

[12] Johnson, S. D., \& Leach, J. A. (2001). Using expert employees to train on the job. Advances in Developing Human Resources, 3(4), 425-434.

[13] Lohman, M. C. (2001). Deductive and inductive on-the-job training strategies. Advances in developing human resources, 3(4), 435-441.

[14] Mathis R. L. dan Jackson J. H, 2006. Manajemen Sumber Daya Manusia. Jilid 1 Edisi Sepuluh. Jakarta: Salemba Empat

[15] Nugroho Wibowo. (2011). Upaya Memper Kecil Kesenjangan Kompetensi Lulusan Sekolah Menengah Kejuruan Dengan Tuntutan Dunia Industri Jurnal Pendidikan Teknologi Dan kejuruan (Vol.23,No 02) hlm 46-50

[16] Osman-Gani, A. M., \& Zidan, S. S. (2001). Cross-cultural implications of planned on-thejob training. Advances in Developing Human Resources, 3(4), 452-460.

[17] Pendidikan, K. (2013). Peraturan Menteri Pendidikan dan Kebudayaan Republik Indonesia. Nomor, 66, 1-3.

[18] Pujianto, P., \& Arief, S. (2017). Pengaruh pengalaman on the job training dan motivasi memasuki dunia kerja terhadap kesiapan kerja siswa. Economic Education Analysis Journal, 6(1), 173-187.

[19] Stein, D. S. (2001). Situated learning and planned training on the job. Advances in Developing Human Resources, 3(4), 415-424.

[20] Stolovitch, H. D., \& Ngoa-Nguele, D. (2001). Structured on-the-job training in developing nations. Advances in Developing Human Resources, 3(4), 461-470.

http://ijstm.inarah.co.id 
International Journal Of Science, Technology \& Management

[21] Swasto, Bambang. 2011. Manjemen Sumber Daya Manusia. Malang: Universitas Brawijaya Press.

[22] Umayah, S. (2017). Pengaruh On The Job Training (OJT), Minat Kerja, dan Bimbingan Karir terhadap Kesiapan Kerja Siswa Kelas XII SMK Negeri 1 Batang (Doctoral dissertation, Universitas Negeri Semarang) 